\title{
Anxiolytic-like activity of zinc in rodent tests
}

\author{
Anna Partyka1 ${ }^{1}$, Magdalena Jastrzębska-Więsek ${ }^{1}$, Bernadeta Szewczyk ${ }^{3}$, \\ Katarzyna Stachowicz ${ }^{3}$, Anna Sławińska ${ }^{3}$, Ewa Poleszak ${ }^{5}$, Urszula \\ Doboszewska ${ }^{2,3}$, Andrzej Pilc ${ }^{3,4}$, Gabriel Nowak2,3 \\ ${ }^{1}$ Department of Clinical Pharmacy, ${ }^{2}$ Department of Pharmacobiology, Jagiellonian University, Collegium Medicum, \\ Medyczna 9, PL 30-688 Kraków, Poland \\ ${ }^{3}$ Department of Neurobiology, Institute of Pharmacology, Polish Academy of Sciences, Smętna 12, \\ PL 31-343 Kraków, Poland \\ ${ }^{4}$ Department of Drug Management, Jagiellonian University, Collegium Medicum, Grzegórzecka 20, \\ PL 31-531 Kraków, Poland \\ ${ }^{5}$ Department of Applied Pharmacy, Skubiszewski Medical University of Lublin, Staszica 4, PL 20-081 Lublin, Poland
}

Correspondence: Anna Partyka, e-mail: mfpartyk@cyf-kr.edu.pl

\begin{abstract}
:
Because zinc deficiency induces depression and anxiety-like behavior in rodents, we examined the effects of zinc administration in several tests by measuring anxiolytic activity in mice and rats. We now report that zinc significantly increased the number of entries into the open arms in the elevated plus maze in rats. Moreover, zinc treatment significantly increased the number of punished crossings in the four-plate test and attenuated stress-induced hyperthermia (SIH) in mice. However, no effect of zinc administration was observed in the elevated plus maze test in mice. This lack of effect in the latter case was probably due to the substantial zinc-induced reduction in locomotor activity by the doses used in mice. The present data demonstrate for the first time the anxiolytic-like activity of zinc in rodents and may indicate that zinc could be used as a novel therapeutic/adjunct agent in anxiolytic therapy.
\end{abstract}

Key words:

zinc, elevated plus maze, stress-induced hyperthermia, four-plate test, mice, rats, anxiolytic activity

\section{Introduction}

Zinc $\left(\mathrm{Zn}^{2+}\right)$ ions rank among the most abundant trace elements in the body. They regulate the function of numerous structural, transcriptional and enzymatic proteins that play important roles in brain function [4, $7,22]$. A substantial fraction of zinc ions is located inside synaptic vesicles of glutamatergic terminals and is released in a calcium-dependent manner [1]. Moreover, $\mathrm{Zn}^{2+}$ is co-released with glutamate [33], in- hibits the glutamate ionotropic N-methyl-D-aspartate (NMDA) receptor complex [3] and inhibits $\mathrm{GABA}_{\mathrm{A}}$ receptors [21]. The highest levels of zinc in the central nervous system (CNS) are present in areas known to be important in depression and anxiety, including the cerebral cortical regions, the hippocampus, most amygdaloid nuclei and the lateral septum [4]. Zinc deprivation influences brain zinc homeostasis and leads to alteration in behavior, learning, mental function and susceptibility to epileptic convulsions [22, 30]. Several studies have indicated that zinc is in- 
volved in the pathophysiology of depression and in the mechanism of action of antidepressants $[5,11,12$, 16]. Preclinical investigations have shown that zinc produces antidepressant-like effects in animal tests (i.e., the forced swim test and the tail suspension test) and in models of depression (i.e., olfactory bulbectomy, chronic unpredictable stress and chronic mild stress) $[6,9,15$, for review 14, 20, 24]. There are also some clinical data showing that zinc supplementation may enhance antidepressant therapy in patients with unipolar depression [13, 23]. Moreover, some preclinical data indicate a correlation between zinc deficiency and an increase in anxiety-like behavior in animal tests of anxiety, i.e., the open field test and the plus maze test in rats and the novelty suppressed feeding test in mice $[31,34]$.

In the present study, we have investigated the effect of acute administration of zinc in the following anxiety tests: the elevated plus maze test in mice and rats, the four-plate test in mice and the stress-induced hyperthermia $(\mathrm{SIH})$ test in mice.

\section{Materials and Methods}

\section{Animals and drug treatment}

All procedures were conducted according to the NIH Animal Care and Use Committee Guidelines and were approved by the Ethical Committee of the Institute of Pharmacology, Polish Academy of Sciences, Collegium Medicum Jagiellonian University in Krakow, and Medical University of Lublin.

The experiments were performed on male Wistar rats (220-280 g) and male albino Swiss mice (22-26 g). The animals were kept under a natural day/night cycle at room temperature $\left(21-23^{\circ} \mathrm{C}\right)$, with free access to food and water. Each experimental group consisted of 6-15 animals. Experiments were conducted between 9:00 a.m. and 2:00 p.m. by an observer who was blinded to the treatment.

Zinc hydroaspartate (Farmapol, Poznań, Poland) dissolved in aqua pro injectione or vehicle (control) was administered intraperitoneally (ip) in a volume of $2 \mathrm{ml} / \mathrm{kg}$ or $10 \mathrm{ml} / \mathrm{kg}$ to rats or mice, respectively, $45 \mathrm{~min}$ before the test. These doses were selected based on previous behavioral data $[9,13]$.

\section{Elevated plus maze test in rats}

The testing procedure was based on a method described by Pellow and File [18]. The plus maze apparatus (an automated device produced by Kinder Scientific) was made of durable, high-density, non-porous black plastic, was elevated to a height of $50 \mathrm{~cm}$ and consisted of two open arms $(50 \times 10 \mathrm{~cm})$ and two closed arms $(50 \times 10 \mathrm{~cm}$ with 30 -cm-high walls $)$, which were arranged so that the two arms of each type were opposite each other. The floor of the plus maze was made of infrared-transparent material; no sensors were visible to the mice. The plus maze was placed in a darkened room, and the center of the apparatus was illuminated with a $25 \mathrm{~W}$ electric bulb hanging $100 \mathrm{~cm}$ above the maze. The plus maze apparatus was connected to PC software by a control chassis. Each rat was gently placed in the center of the plus maze, facing one of the closed arms, immediately after a 5-min adaptation period in a black plastic box $(60 \times 60 \times 35 \mathrm{~cm})$. During a 5-min test period, the automated Kinder Scientific Motor Monitor System recorded the number of entries into the closed and open arms, the time spent in each and the distance $(\mathrm{cm})$ covered by a rat in each type of arm. After each trial, the maze was wiped clean.

\section{Exploratory activity measured in the elevated plus maze in rats}

The experiment was performed using a plus maze apparatus (an automated device produced by Kinder Scientific) (see above). During a 5-min test period (i.e., the time equal to the observation period in the elevated plus maze), the automated Kinder Scientific Motor Monitor System recorded the total time spent in the open and closed arms, the total entries, the total distance and $\mathrm{X}$ and $\mathrm{Y}$ ambulation; changes in these parameters would indicate that treatment with zinc affected general locomotor activity rather than anxietylike behavior specifically. After each trial, the maze was wiped clean.

\section{Four-plates test}

A single mouse was placed gently onto the plate, and each animal was allowed to explore for $15 \mathrm{~s}$. After this time, each time a mouse passed from one plate to another, the experimenter electrified the whole floor for $0.5 \mathrm{~s}$ (current intensity $0.8 \mathrm{~mA}$ ), which evoked 
a visible flight reaction from the animal. If the animal continued running, it received no new shock for the following $3 \mathrm{~s}$. The number of punished crossings was counted for $60 \mathrm{~s}$ [2].

\section{Modified stress-induced hyperthermia (SIH) test in singly-housed mice}

The procedure for the modified stress-induced hyperthermia test was adapted from Van der Heyden et al. [32]. For this assay, body temperature was measured in each mouse at $\mathrm{t}=0 \mathrm{~min}\left(\mathrm{~T}_{1}\right)$ and $\mathrm{t}=15 \mathrm{~min}\left(\mathrm{~T}_{2}\right)$. Albino Swiss mice were placed into a new cage immediately following measurement of $T_{1}$, with the difference in temperature $\left(\mathrm{T}_{2}-\mathrm{T}_{1}\right)$ used as a measure of stressinduced hyperthermia. Pilot studies by Spooren et al. [25] demonstrated that a $\mathrm{T}_{2}-\mathrm{T}_{1}$ interval of $15 \mathrm{~min}$ is optimal for the measurement of SIH. A comparison between $\mathrm{T}_{1}$ in vehicle-treated mice and $\mathrm{T}_{1}$ in testcompound-treated mice was used to determine whether the agent alone affects body temperature. Rectal temperature was measured to the nearest $0.1^{\circ} \mathrm{C}$ by an Ellab thermometer. The lubricated thermistor probe $(2 \mathrm{~mm}$ diameter) was inserted $20 \mathrm{~mm}$ into the rectum. The mouse was held at the base of the tail during this determination, and the thermistor probe was left in place until a constant reading was obtained $( \pm 15 \mathrm{~s})$.

\section{Elevated plus maze test in mice}

The EPM studies were conducted on mice according to the method of Lister [10]. The EPM apparatus was made of Plexiglas and consisted of two open $(30 \times 5 \mathrm{~cm})$ and two enclosed $(30 \times 5 \times 15 \mathrm{~cm})$ arms. The arms extended from a central platform of $5 \times 5 \mathrm{~cm}$. The apparatus was mounted on a Plexiglas base, raising it $38.5 \mathrm{~cm}$ above the floor, and was illuminated by a red light. The test was performed by placing a mouse in the center of the apparatus (facing an enclosed arm) and allowing it to freely explore. The number of entries into the open arms and the time spent in these arms were scored for a 5-min test period. An entry was defined as placing all four paws within the boundaries of the arm. The following measures were obtained from the test: the total number of arm entries; the percentage of arm entries into the open arms; and the time spent in the open arms expressed as a percentage of the time spent in both the open and closed arms. Anxiolytic activity was indicated by increases in the time spent in open arms or in the number of open arm entries.

\section{Locomotor activity in mice}

The actimeter consisted of a cylinder $(30 \mathrm{~cm}$ in diameter, $12 \mathrm{~cm}$ high, MultiServ, Lublin, Poland) equipped with two perpendicular infrared light beams located $1.5 \mathrm{~cm}$ above the floor. Mice were placed in the actimeter, and locomotor activity (the number of interruptions of light beams) was recorded for a period of 5 min after placing each mouse into the actimeter.

\section{Data analysis}

The data were evaluated by a one-way analysis of variance (ANOVA) followed by the Newman-Keuls Multiple Comparison test. A p value less than 0.05 was considered significant.

\section{Results and Discussion}

Preclinical and clinical evidence from the last ten years indicates that zinc is involved in the pathophysiology of depression and in the mechanism of action of antidepressants [26-28]. Its antidepressant effects have been demonstrated in a number of animal tests and models of depression and in clinical studies. Moreover, it was recently demonstrated that zinc deficiency induces depression- and anxiety-like behavior in rodents [31, 34].

In this study, we examined for the first time the anxiolytic-like effects of acute treatment with zinc hydroaspartate in the following animal tests commonly used to predict the potential anxiolytic activity of a drug in humans: the elevated plus maze test in rats and mice, the four-plate test in mice and the stressinduced hyperthermia test in mice.

The effects of acute treatment with zinc hydroaspartate on rats in the elevated plus maze are shown in Table 1. In this test, zinc hydroaspartate was administered at doses of $65,32.5,16.25$ and $8.125 \mathrm{mg} / \mathrm{kg}$. Zinc given at doses of 32.5 and $16.25 \mathrm{mg} / \mathrm{kg}$ significantly increased (up to $42 \%$ and $39 \%$, respectively) the percentage of entries into the open arms [ANOVA: $\mathrm{F}(4,87)=4.6271, \mathrm{p}=0.00196]$. However, the percentage of time spent in the open arms did not reach the level of statistical significance. The anxiolytic-like effect of zinc hydroaspartate in the elevated plus maze test seems to be specific, as it did not sig- 
Tab. 1. The effect of zinc hydroaspartate on percent of time spent in open arms, percent of open arms entries and exploratory activity in the elevated plus maze test in rats

\begin{tabular}{cccccc}
\hline Compound & $\begin{array}{c}\text { Dose } \\
(\mathrm{mg} / \mathrm{kg})\end{array}$ & $\begin{array}{c}\text { Percent of time } \\
\text { spent in open arms }\end{array}$ & $\begin{array}{c}\text { Percent of open } \\
\text { arms entries }\end{array}$ & $\begin{array}{c}\text { Total distance } \\
(\mathrm{cm})\end{array}$ & Total entries \\
\hline Vehicle & - & $18.0 \pm 2.4$ & $29.0 \pm 2.5$ & $3499 \pm 123$ & $24.0 \pm 1.5$ \\
Zn & 8.125 & $20.6 \pm 5.1$ & $31.8 \pm 5.4$ & $3475 \pm 332$ & $22.4 \pm 3.7$ \\
& 16.25 & $22.6 \pm 3.4$ & $42.1 \pm 3.6^{\star \star}$ & $2977 \pm 245$ & $18.4 \pm 2.6$ \\
& 32.5 & $23.2 \pm 2.5$ & $39.4 \pm 2.7^{\star}$ & $3154 \pm 217$ & $20.7 \pm 2.0$ \\
& 65.0 & $16.9 \pm 4.8$ & $22.2 \pm 5.1$ & $3857 \pm 199$ & $25.8 \pm 3.7$ \\
\hline
\end{tabular}

Zinc hydroasparatate was administrated ip 45 min before the test. Data were assessed by a one-way ANOVA followed by the Newman-Keuls Multiple Comparison test. Each column represents the mean \pm SEM of $12-15$ rats per group. ${ }^{*} p<0.05,{ }^{* *} p<0.02$ vs. vehicle-treated control group

nificantly affect the exploratory activity of the animals (total entries and total distance). The remaining two doses of the compound ( 65 and $8.125 \mathrm{mg} / \mathrm{kg}$ ) did not produce any effects characteristic of anxiolytics in this test.

The effects of acute treatment with zinc hydroaspartate on mice in the four-plate test are shown in Figure 1 . Zinc hydrosapartate at a dose of $10 \mathrm{mg} / \mathrm{kg}$ significantly increased the number of punished crossings [ANOVA: $\mathrm{F}(2,25)=4.317, \mathrm{p}=0.0245]$. The higher dose of this compound had no effect in the test.

The effects of acute treatment with zinc hydroaspartate on stress-induced hyperthermia $(\mathrm{SIH})$ in mice are shown in Figure 2. SIH was significantly attenuated by zinc treatment [ANOVA: F $(3,34)=2.902, \mathrm{p}=$ 0.0489]. Post-hoc comparison showed that zinc was

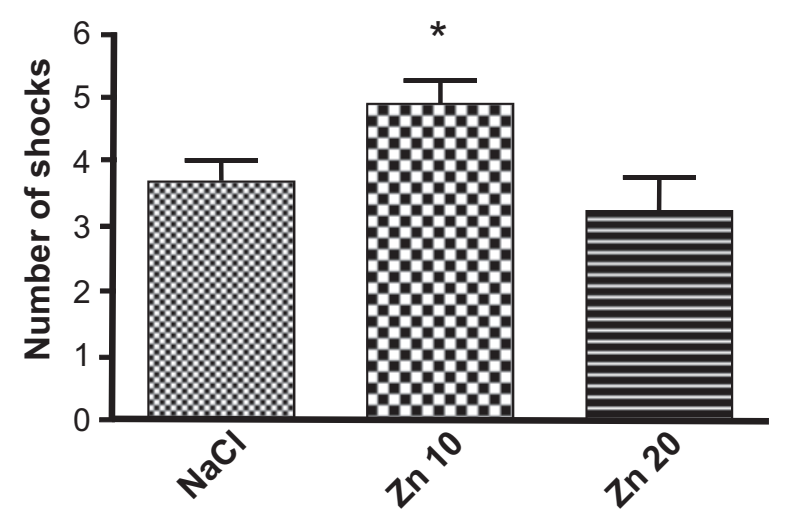

Fig. 1. The effect of zinc hydroaspartate on the number of shocks accepted in the four-plate test in mice. Zinc hydroaspartate was administrated ip 45 min before the test. Data were assessed by a one-way ANOVA followed by the Newman-Keuls Multiple Comparison test. Each column represents the mean \pm SEM of 8-10 mice per group. ${ }^{*} \mathrm{p}<0.05$ vs. vehicle-treated control group significantly effective in reducing SIH only at a dose of $2.5 \mathrm{mg} / \mathrm{kg}$.

In the plus maze test in mice, zinc did not influence the number of open arms entries and time spent on the open arms (data not shown). On the other hand, zinc hydroaspartate at doses of $2.5,5,10 \mathrm{mg} / \mathrm{kg}$ significantly decreased the locomotor activity (the number of animal movements measured by the actimeters, Table 2 [ANOVA: $F(3,35)=19.09, \mathrm{p}<0.0001])$.

As shown above, we have observed anxiolytic-like effects of zinc in most of the animal tests used: it altered the number of shocks accepted in the four-plate test in mice even though it decreased the locomotor activity of animals; it also significantly reduced stress-induced hyperthermia and increased the percentage of open arms entries in the elevated plus maze

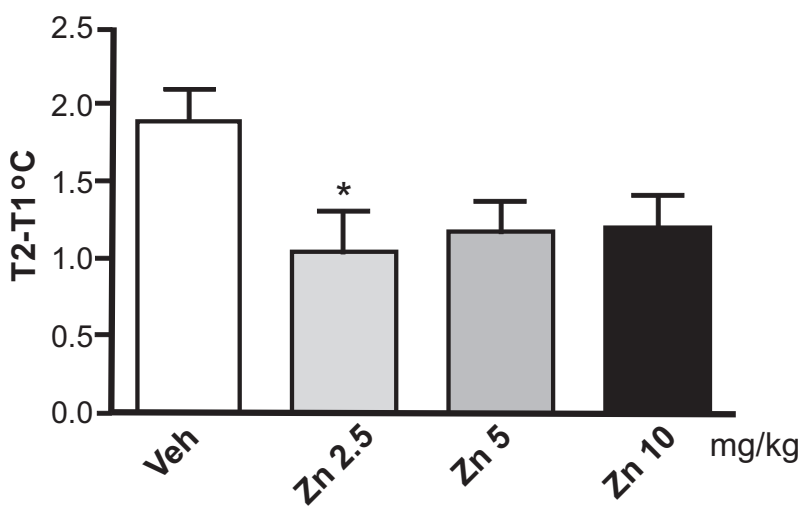

Fig. 2. The effect of zinc hydroaspartate on stress-induced hyperthermia $(\mathrm{SIH})$ in mice. Zinc hydroaspartate was administered ip $45 \mathrm{~min}$ before the test. Data were assessed by a one-way ANOVA followed by the Newman-Keuls Multiple Comparison test. Each column represents the mean \pm SEM of 8-10 mice per group. * $p<0.05$ vs. vehicle-treated control group 
Tab. 2. Effect of zinc hydroaspartate administration on locomotor activity in mice

\begin{tabular}{ccc}
\hline Compound & Dose $(\mathrm{mg} / \mathrm{kg})$ & Locomotor activity/5 min \\
\hline Vehicle & - & $115.0 \pm 8.5$ \\
Zn & 2.5 & $78.0 \pm 7.8^{*}$ \\
& 5.0 & $55.1 \pm 3.7^{*}$ \\
& 10.0 & $43.1 \pm 7.6^{*}$ \\
\hline
\end{tabular}

Zinc hydroaspartate was administrated ip 45 min before the test Data were assessed by a one-way ANOVA followed by the Newman-Keuls Multiple Comparison test. Each column represents the mean \pm SEM of $8-10$ mice per group. ${ }^{\star} p<0.05$ vs. vehicletreated control group

test in rats but not in mice. The lack of an effect in mice was probably due to the substantial zinc-induced reduction in locomotor activity.

The mechanism responsible for the anxiolytic action of zinc is probably related to the modulation of glutamate and/or GABA-ergic systems. Based on the results of experiments examining the mechanism of zinc antidepressant-like activity, we can speculate that the anxiolytic activity of zinc (like organic NMDA receptor antagonists, e.g., $[8,19])$ may be related to its antagonism of NMDA and/or mGluR5 glutamate receptors [17 for review]. However, zinc action through GABA-ergic or serotonergic receptors cannot be disregarded [29]. Further studies are needed to evaluate the exact mechanism(s) responsible for the anxiolytic activity of zinc.

Overall, our data show for the first time the anxiolytic-like effects of zinc hydroaspartate, as evaluated by three tests in rats and mice. These data should encourage further examination of anxiolytic zinc activity and may indicate that zinc could be used as a novel therapeutic/adjunct agent in anxiolytic therapy.

\section{References:}

1. Ahn YH, Kim YH, Hong SH, Koh JY: Depletion of intracellular zinc induces protein synthesis-dependent neuronal apoptosis in mouse cortical culture. Exp Neurol, 1998, 154, 47-56.

2. Boissier JR, Simon P, Aron C: A new method for the rapid screening of minor tranquillizers in mice. Eur J Pharmacol, 1968, 4, 145-151.

3. Bresink I, Danysz W, Parsons CG, Mutschler E: Different binding affinities of NMDA receptor channel blockers in various brain regions - indication of NMDA receptor heterogeneity. Neuropharmacology, 1995, 34, 533-540.

4. Brown CE, Dyck RH: Distribution of zincergic neurons in the mouse forebrain. J Comp Neurol, 2004, 479, 156-167.

5. Cichy A, Sowa-Kućma M, Legutko B, PomiernyChamioło L, Siwek A, Piotrowska A, Szewczyk B et al.: Zinc-induced adaptive changes in NMDA/glutamatergic and serotonergic receptors. Pharmacol Rep, 2009, 61, 1184-1191.

6. Cieślik K, Klenk-Majewska B, Danilczuk Z, Wróbel A, Łupina T, Ossowska G: Influence of zinc supplementation on imipramine effect in chronic unpredictable stress (CUS) model in rats. Pharmacol Rep, 2007, 59, 46-52.

7. Frederickson CJ, Suh SW, Silva D, Frederickson CJ, Thompson RB: Importance of zinc in the central nervous system: the zinc-containing neuron. J Nutr, 2000, 130, 1471S-1483S

8. Kotlinska J, Liljequist S: A characterization of anxiolytic-like actions induced by the novel NMDA/glycine site antagonist, L-701,324. Psychopharmacology, 1998, $135,175-181$

9. Kroczka B, Brański P, Pałucha A, Pilc A, Nowak G: Antidepressant-like properties of zinc in rodent forced swim test. Brain Res Bull, 2001, 55, 297-300.

10. Lister LG: The use of a plus-maze to measure anxiety in the mouse. Psychopharmacology, 1987, 92, 180-185.

11. Maes M, D'Haese PC, Scharpe S, D'Hondt PD, Cosyns P, De Broe ME: Hypozincemia in depression. J Affect Disord, 1994, 31, 135-140.

12. McLoughlin IJ, Hodge SJ: Zinc in depressive disorder. Acta Psychiatr Scand, 1990, 82, 451-453.

13. Nowak G, Siwek M, Dudek D, Zięba A, Pilc A: Effect of zinc supplementation on antidepressant therapy in unipolar depression: a preliminary placebo-controlled study. Pol J Pharmacol, 2003, 55, 1143-1147.

14. Nowak G, Szewczyk B, Pilc A: Zinc and depression. An update. Pharmacol Rep, 2005, 57, 713-718.

15. Nowak, G, Szewczyk B, Wierońska JM, Brański P, Pałucha A, Pilc A, Sadlik K, Piekoszewski W: Antidepressant-like effects of acute and chronic treatment with zinc in forced swim test and olfactory bulbectomy model in rats. Brain Res Bull, 2003, 61, 159-164.

16. Opoka W, Sowa-Kućma M, Stachowicz K, Ostachowicz B, Szlósarczyk M, Stypuła A, Młyniec K et al.: Early lifetime zinc supplementation protects zinc-deficient dietinduced alterations. Pharmacol Rep, 2010, 62, 1211-1217.

17. Paoletti P, Vergnano AM, Barbour B, Casado M: Zinc at glutamatergic synapses. Neuroscience, 2009, 158, 126-136.

18. Pellow S, File SE: Anxiolytic and anxiogenic drug effects on exploratory activity in an elevated plus-maze: a novel test of anxiety in the rat. Pharmacol Biochem Behav, 1986, 24, 525-529.

19. Plaznik A, Palejko W, Nazar M, Jessa M: Effects of antagonists at the NMDA receptor complex in two models of anxiety. Eur Neuropsychopharmacol, 1994, 4, 503-512.

20. Rodrigues AL, Rosa AO, Lin J, Calixto JB, Santos AR: Antidepressant-like effects of zinc in mice: possible involvement of NMDA receptors and L-arginine-nitric oxide pathway. Eur Neuropsychopharmacol, 2002, 12, Suppl 3, 222. 
21. Ruiz A, Walker MC, Fabian-Fine R, Kullmann DM: Endogenous zinc inhibits $\mathrm{GABA}_{\mathrm{A}}$ receptors in a hippocampal pathway. J Neurophysiol, 2004, 91, 1091-1096.

22. Sandstead HH, Frederickson CJ, Penland JG: History of zinc as related to brain function. J Nutr, 2000, 130, 496S-502S

23. Siwek M, Dudek D, Paul IA, Sowa-Kućma M, Zieba A, Popik P, Pilc A, Nowak G: Zinc supplementation augments efficacy of imipramine in treatment resistant patients: A double blind, placebo-controlled study. J Affect Disord, 2009, 118, 187-95.

24. Sowa-Kućma M, Legutko B, Szewczyk B, Novak K, Znojek P, Poleszak E, Papp M et al.: Antidepressant-like activity of zinc: further behavioral and molecular evidence. J Neural Transm, 2008, 115, 1621-1628.

25. Spooren WP, Schoeffter P, Gasparini F, Kuhn R, Gentsch $\mathrm{C}$ : Pharmacological and endocrinological characterization of stress-induced hyperthermia in singly housed mice using classical and candidate anxiolytics (LY314582, MPEP and NKP608). Eur J Pharmacol, 2002, 435, 161-70.

26. Szewczyk B, Kubera M, Nowak G: The role of zinc in neurodegenerative inflammatory pathways in depression. Progr Neuro-Psychopharmacol Biol Psychiatry, 2011, 35, 693-701.

27. Szewczyk B, Poleszak E, Pilc A, Nowak G: Ionic glutamate modulators in depression (Zinc, Magnesium). In: Glutamate-based Therapies for Psychiatric Disorders. Ed. Skolnick P, Series: Milestones in Drug Therapy, (Parnham MJ, Bruinvels J; series editors), Springer Basel AG, 2010, 21-38.
28. Szewczyk B, Poleszak E, Sowa-Kućma M, Siwek M, Dudek D, Ryszewska-Pokraśniewicz B, RadziwońZaleska $M$ et al.: Antidepressant activity of zinc and magnesium in view of current hypotheses of antidepressant action. Pharmacol Rep, 2008, 60, 588-599.

29. Szewczyk B, Poleszak E, Wlaź P, Wróbel A, Blicharska E, Cichy A, Dybała M et al.: The involvement of serotonergic system in the antidepressant effect of zinc in the forced swim test. Prog Neuropsychopharmacol Biol Psychiatry, 2009, 33, 323-329.

30. Takeda A: Movement of zinc and its functional significance in the brain. Brain Res Rev, 2000, 34, 137-148.

31. Takeda A, Tamano H, Kan F, Itoh H, Oku N: Anxietylike behavior of young rats after 2-week zinc deprivation. Behav Brain Res, 2007, 177, 1-6.

32. Van der Heyden JAM, Zethof TJJ, Olivier B: Stressinduced hyperthermia in singly housed mice. Physiol Behav, 1997, 62, 463-470.

33. Vogt K, Mellor J, Tong G, Nicoll R: The actions of synaptically released zinc at hippocampal mossy fiber synapses. Neuron, 2000, 26, 187-196.

34. Whittle N, Lubec G, Singewald N: Zinc deficiency induces enhanced depression-like behavior and altered limbic activation reversed by antidepressant treatment in mice. Amino Acids, 2009, 36, 147-158.

Received: January 14, 2011; in the revised form: February 17, 2011; accepted: February 23, 2011. 